\title{
Kuinka avoimen yliopiston opiskelija yhdistää opiskelun, työn ja perheen
}

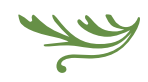

\begin{abstract}
Aikuisopiskelijoiden motiivit avoimessa yliopistossa opiskeluun vaihtelevat tutkinnon tavoittelusta ammatilliseen pätevöitymiseen ja yleiseen sivistymiseen. Työn ja perheen yhdistäminen opiskeluun on aikuisopiskelijan kestohaaste.
\end{abstract}

AVOIN YLIOPISTO tarjoaa koulutuspohjasta riippumatta mahdollisuuden opiskella yliopistollisia opintoja. Haltian $(2012,261)$ mukaan avointa yliopistoa voidaan nykyisin pitää opiskelufoorumina, joka palvelee joustavasti opiskelijoiden erilaisia tarpeita. Opiskelijat tulevat avoimeen yliopistoon usein yksilöllisen kiinnostuksensa pohjalta ja heidän tavoitteensa vaihtelevat. Opiskelua voi motivoida tutkinnon tavoittelu, ammatillinen lisäpätevöityminen, yleinen sivistyminen tai harrastaminen (Müller \& Repo 2013; Repo 2010; Rinne ym. 2003). Ammatilliset tavoitteet ja tutkintotavoitteet ovat 2000-luvulla vahvistuneet sivistystavoitteisen opiskelun rinnalla (Haltia 2012).

Suurinta osaa avoimen yliopiston opiskelijoista voidaan pitää ikänsä puolesta aikuisopiskelijoina. Esimerkiksi Helsingin yliopiston Avoimen yliopiston opiskelijoista yli 24-vuotiaita oli vuonna 2012 noin kolme neljäsosaa (Helsingin yliopiston Avoi- men yliopiston sisäinen tilasto). Aikuisena opiskelun suurin haaste liittyy elämäntilanteeseen. Revon (2010, 146) mukaan yli puolet opiskelijoista kokee elämäntilanteen tai resurssien puutteen hidastavan opintoja. Työn ja perheen yhdistäminen opiskeluun avoimessa yliopistossa ei aina onnistu suunnitelmien mukaan (Purtilo-Nieminen \& Määttä 2011). Elämäntilanteen lisäksi muut ulkoiset tekijät, kuten oppimisympäristön, opetuksen ja ohjauksen puutteet olivat opiskelijoiden mainitsemia yleisempiä syitä opintojen hidastumiselle (Repo 2010, 146).

Osa aikuisopiskelijoista saa sovitettua yliopistollisen opiskelun osaksi omaa arkeaan ja saavuttaa asettamansa tavoitteet. Haarala-Muhosen $(2011,56)$ oikeustieteen opiskelijoista tekemän tutkimuksen mukaan itsesäätelytaidot ovat tärkeitä opintojen etenemisen kannalta. Itsesäätelytaidoilla tarkoitetaan oppimisen yhteydessä sitä, että opiskelija osaa aset- 
taa realistiset tavoitteet, ottaa vastuun omasta työskentelystään sekä pystyy pitämään yllä opiskelumotivaatiotaan vastoinkäymisistä huolimatta (Zimmerman 2000; Pintrich 2003a; Vermunt and Vermetten 2004). Haarala-Muhosen $(2001,47)$ mukaan nopeasti edenneitä opiskelijoita yhdisti se, että he tunnistivat itselleen parhaat tavat oppia ja opiskella. He käyttivät myös useita erilaisia opiskelustrategioita ja pyysivät apua toisilta opiskelijoilta, jos he eivät olleet ymmärtäneet lukemaansa. Sen sijaan hitaasti edenneillä opiskelijoilla ajanhallinta oli vaikeaa, ja he kokivat, etteivät voineet itse vaikuttaa siihen. Samanlaiset itsesäätelyn haasteet koskenevat myös Avoimen yliopiston opiskelijoita, vaikkakin varhaisemmissa, 1980- ja 1990-luvun tutkimuksissa Avointa yliopistoopiskelijaa lähestyttiin itseohjautuvana, oman oppimisensa subjektina (Haltia 2012, 154). Myöhemmin tätä tutkimusta on kuitenkin kritisoitu muun muassa siitä, että itseohjautuvuus nähtiin liiaksi yksinohjautuvuutena (Pasanen 2001).

Törmän ja Mäkisen (2012) mukaan opiskelutaitojen puutteiden tunnistaminen edistää laadukasta oppimista avoimen yliopiston opiskelijoilla. Revon $(2010,146)$ tutkimuksessa kuitenkin vain viisi prosenttia avoimen yliopiston opiskelijoista ilmoitti opintojen hidastumisen syyksi opiskelutaitojen puutteen. Voidaankin ajatella, että opiskelijat eivät helposti itse tunnista, mikä merkitys opiskelutaidoilla ja ajanhallinnalla on opintojen etenemiseen.

Suomessa avoimen yliopiston opintoja on tarjolla lähiopetuksena, etäopetuksena verkon välityksellä tai näiden yhdistelmänä ja opiskelija voi valita elämäntilanteeseensa sopivan opiskelumuodon. Avoimen yliopiston idea haastaa perinteisen yliopistojen kampus-ajattelun (Guri-Rosenblit 1999), eivätkä avoimen yliopiston opiskelijat pääse perustutkinto-opiskelijoiden lailla luontevasti osaksi yliopistoyhteisöä sekä laajempaa asiantuntijayhteisöä. Kuitenkin asiantuntijaksi kasvaminen vaatii kiinnittymistä juuri kyseisen alan asiantuntijayhteisöön (Wenger 1998; Mäkinen \& Annala 2011, 59; Korhonen 2012).

Asiantuntijayhteisöön kasvamisessa on tärkeä samaistua sekä opettajiin että vertaisiin (Lähteenoja 2010). Revon mukaan (2010) opiske- lijat eivät välttämättä huomaa toisten opiskelijoiden merkitystä opinnoille. Hänen tutkimuksessaan noin 10 prosenttia opiskelijoista koki vertaistuen opiskelua edistäväksi tekijäksi, kun taas hidasteena tai ongelmana sen koki vain alle yksi prosentti vastaajista (Repo 2010, 154; vrt. Hailikari \& Sjöblom 2012, 28). Jyväskylän yliopiston opiskelijoista tehdyt tutkimukset toisaalta osoittavat, että vertaistuki on merkittävä ohjaustaho koko opintopolun ajan (Lairio \& Penttinen 2005; Törmä \& Mäkinen 2012). Aikuisopiskelijoilla on usein pysyvät tukiverkostot ja Revon (2010, 154) mukaan perhe, ystävät ja työtoverit muodostavatkin opiskelijatovereiden lisäksi avoimen opiskelijoille tärkeän tukiverkoston.

Partanen (2011) on lisäksi tuonut esiin myönteisten minäpystyvyysuskomusten merkityksen avoimen opiskelijoiden opintojen etenemiselle. Minäpystyvyysuskomus (self-efficacy) on alun perin Albert Banduran käsite, joka tarkoittaa sitä, miten yksilö uskoo omaan pätevyyteensä suoriutua tietyistä tehtävistä (Bandura 1977).

Tässä tutkimuksessa olemme kiinnostuneita siitä, minkälaisia haasteita avoimen yliopiston opiskelijat kokevat opiskelussaan. Lisäksi kysymme, eroavatko avoimen opiskelijat sukupuolen, koulutuksen tai iän suhteen siinä, minkälaisia haasteita he opinnoissaan kokevat. Lopuksi pohdimme, minkälaisesta tuesta avoimen yliopiston opiskelijat voisivat hyötyä.

\section{TUTKIMUSAINEISTO JA SEN ANALYYSI}

Tämän tutkimuksen aineisto koostuu kahdesta erillisestä kyselystä, jotka molemmat kerättiin keväällä 2011 sähköisellä kyselylomakkeella. Toinen aineisto on kerätty osana Helsingin yliopiston Avoimen yliopiston TNS Gallupilta tilaamaa selvitystä Tutkimus avoimista yliopisto-opinnoista 2011 (jäljempänä Koulutustarveselvitys). Tässä tutkimuksessa haluttiin selvittää erityisesti pääkaupunkiseudun avoimen yliopisto-opintojen tarvetta. Toinen osa-aineisto on kansainvälisen projektin Opening Universitites for Lifelong Learning (jäljempänä OPULL) Suomen aineisto. Hankkeen tavoitteena oli vertailla eri maiden (Saksa, Iso-Britannia, Tanska ja Suomi) yliopistojärjestelmien avoimuutta ja luoda malli eurooppalaisten yliopistojen avoimuuden lisäämiseksi. 
Molempien kyselyiden otokseen valittiin satunnaisesti opiskelijat niiden opiskelijoiden keskuudesta, joilla oli keväällä 2011 voimassa opiskeluoikeus Helsingin yliopiston Avoimen yliopiston opintoihin. Koulutustarveselvitykseen vastasi 367 henkilöä ja OPULL-hankkeen kyselyyn 313 opiskelijaa. Taulukosta 1 voi nähdä tarkempia vastaajien tunnuslukuja. Verrattuna Helsingin yliopiston Avoimen yliopiston vuoden 2001 tilastoihin naiset olivat yliedustettuina aineistoissa. Vuonna 2011 Helsingin yliopiston Avoimessa yliopistossa 76 prosenttia opiskelijoista oli naisia. Vastaajat olivat myös keskimäärin vanhempia kuin perusjoukossa. Molemmissa aineistoissa ikäryhmät alle 25 ja 25-29 olivat aliedustettuina ja ikäryhmät 40-49 ja 50-59 olivat yliedustettuina. Koulutustarveselvitykseen vastanneiden koulutustaustaa ei voida luotettavasti verrata virallisiin tilastoihin, koska luokittelut poikkeavat toisistaan. OPULLaineistossa ylioppilaiden määrä on sama kuin virallisissa tilastoissa, sen sijaan korkeakoulutettujen määrä on hieman korkeampi.

Opiskelun haasteita tutkittiin sekä kvantitatiivisesti että kvalitatiivisesti. Kvantitatiivinen likert-asteikollinen mittari käsitti alun perin 14 väitettä. Väitteet laadittiin OPULL-tutkimushankkeen kansainvälisessä tutkimusryhmässä ottaen huomioon eri maiden opiskelijoiden toimintaympäristöt. Aineistolle tehtiin faktorianalyysi Varimax-rotaatiolla, ja ratkaisu pakotettiin kolmeen luokkaan. Faktorianalyysin tuloksena saatiin teoreettisesti mielekkäät ja reliabiliteetiltaan riittävän hyvät faktorit, joiden pohjalta muodostettiin summamuuttujat. Lopullisiin summamuuttujiin otettiin mukaan 11 väittämää. Summamuuttujat olivat Itseluottamuksen, motivaation ja opiskelukykyjen puute $(\alpha=0.776)$, Vuorovaikutuksen puute $(\alpha=0.743)$ ja Elämän eri osa-alueiden yhteensovittamisen haasteet $(\alpha=0.681)$. Tutkittaessa taustamuuttujien yhteyttä summamuuttujiin, käytettiin t-testiä ja yksisuuntaista varianssianalyysia (ANOVA), koska summamuuttujien vinousarvot olivat alle yhden. Ryhmien parittaisissa vertailuissa käytettiin Tukeyn testiä.

Kaksi muuta opiskelun haasteita kartoittavaa kysymystä oli avoimia. OPULL-hankkeessa kysyttiin ”Jos koet, että sinua ei ole tuettu hyvin, kerro siitä lisää” ja Koulutustarveselvityksessä kysyttiin "Miksi olet keskeyttänyt/harkinnut avoimen yliopisto-opintojen keskeyttämistä?”. Nämä kaksi aineistoa yhdistettiin, ja niitä analysoi sisällönanalyysillä kaksi eri tutkijaa. Ensin molemmat luokittelivat aineistolähtöisesti ja toisistaan riippumatta aineiston alaluokkiin. Yhteisen keskustelun pohjalta tarkennettiin alaluokkia ja muodostettiin niiden pohjalta pääluokat. Pääluokkien muodostamisen myötä myös alaluokat tarkentuivat entisestään (ks. Tuomi \& Sarajärvi 2003, 112-114).

\section{TULOKSET}

Vastaajat kokivat elämän eri osa-alueiden yhteensovittamisen selvasti suurimpana haasteena. Vuorovaikutuksen sekä itseluottamuksen, motivaation ja opiskelukykyjen puutteet koettiin vähäisemmiksi ongelmiksi, mutta silti opiskelijat tunnistavat myös näiden merkityksen opintojen esteinä. Summamuuttujien keskiarvot ja hajonnat näkyvät taulukossa 2.

Kun haasteiden kokemista vertailtiin eri taustamuuttujien suhteen, voitiin havaita, että miehet ja naiset eivät eronneet toisistaan. Myöskään ikäryhmien (alle 25-vuotiaat, 25-29, 30-39, 40-49, 50-59,

Taulukko 1. Tutkimusaineistojen tunnuslukuja.

\begin{tabular}{|c|c|c|}
\hline AINEISTO & OPULL & KOULUTUSTARVEKARTOITUS \\
\hline Vastaajien määrä (vastausprosentti) & $313(21 \%)$ & $367(17 \%)$ \\
\hline Naisia & $83 \%$ & $81 \%$ \\
\hline Ylioppilas/ylin koulutus ylioppilas & $86 \%$ ylioppilaita & $26 \%$ ylin koulutus ylioppilastutkinto \\
\hline Keski-ikä/suurin ikäryhmä & keski-ikä 38 vuotta & suurin ikäryhmä 30-39-vuotiaat (27 \%) \\
\hline Yliopistotutkinto/ylempi korkeakoulututkinto & $36 \%$ yliopistotutkinto & $25 \%$ ylempi korkeakoulututkinto \\
\hline $\begin{array}{l}\text { Ammattikorkeakoulututkinto/ } \\
\text { ammattikorkeakoulututkinto, ylempi } \\
\text { opistoasteen tutkinto tai alempi } \\
\text { korkeakoulututkinto }\end{array}$ & $25 \%$ ammattikorkeakoulututkinto & $\begin{array}{l}35 \% \text { ammattikorkeakoulututkinto, } \\
\text { ylempi opistoasteen tutkinto tai alempi } \\
\text { korkeakoulututkinto }\end{array}$ \\
\hline
\end{tabular}


60-vuotiaat ja sitä vanhemmat) välillä ei ollut eroa itseluottamuksen, motivaation ja opiskelukykyjen tai vuorovaikutuksen kokemisessa. Elämän eri osa-alueiden yhteensovittamisessa ryhmien välillä sen sijaan oli tilastollisesti merkitsevä ero, F $(5,307)=8,39$ p < 0.001 , ja parittaisten vertailujen perusteella voitiin havaita, että vain 60-vuotiaat ja sitä vanhemmat kokivat selvästi vähiten haasteita verrattuna muihin ikäryh$\operatorname{miin}(\mathrm{n}=12, \mathrm{ka}=1,89 \mathrm{jakh}=0,81$, Tukeyn testi, $\mathrm{p}<0.05)$. Muuten ikäryhmien välillä ei ollut tilastollisesti merkitseviä eroja.

Koulutuksen yhteyttä haasteiden kokemiseen tutkittiin t-testillä ja yksisuuntaisella varianssianalyysillä (ANOVA). Ylioppilailla ja ei-ylioppilailla ei ollut eroa siinä, miten haastavana he kokivat elämän eri osa-alueiden yhteensovittamisen tai vuorovaikutuksen puutteen. Sen sijaan ei-ylioppilaat $(\mathrm{n}=43, \mathrm{ka}=2,34, \mathrm{kh}=0,68)$ kokivat enemmän itseluottamuksen, motivaation ja opiskelukykyjen puutetta kuin ylioppilaat $(\mathrm{n}=261, \mathrm{ka}=2,07, \mathrm{kh}=0,76)(\mathrm{t}$-testi, $\mathrm{p}<0.05)$. Myös jatkokoulutuksen (luokat: toisen asteen ammatillinen koulutus, opistoasteen koulutus, ammattikorkeakoulu, yliopisto, muu/ei ammatillista tai korkeakoulutusta) osalta tulokset olivat samansuuntaisia: varianssianalyysin mukaan eroja eri koulutusryhmien välillä oli siinä, miten vastaajat kokivat itseluottamuksen, motivaation ja opiskelukykyjen $\mathrm{F}(4)=5.26, \mathrm{p}<0.001)$ tai vuorovaikutuksen puutetta $\mathrm{F}(4)=4.62, \mathrm{p}<0,001$. Yliopistotutkinnon suorittaneiden ryhmä koki vähiten itseluottamuksen, motivaation ja opiskelukykyjen haasteita $(\mathrm{n}=112, \mathrm{ka}=1,87, \mathrm{kh}=0,72)$, ja ero oli tilastollisesti merkitsevä tai lähes merkitsevä suhteessa muihin paitsi opistoasteen koulutuksen saaneisiin $(p=0.002-0.024)$. Vuorovaikutuksen puutteen osalta ero oli tilastollisesti lähs merkitsevä yliopistotutkinnon suorittaneilla $(\mathrm{x}=1,86, \mathrm{kh}=0,91)$ suhteessa toisen asteen ammatillisen koulutuksen saaneisiin $(n=29, x=2,44, k h=0,99)(p<0.05) j a$ merkitsevä suhteessa ammattikorkeakoulutuksen saaneiden ryhmään $(\mathrm{n}=77, \mathrm{ka}=2,32, \mathrm{kh}=0,86)$ $(p<0.01)$. Kun verrattiin opiskelijoita sen mukaan, ilmoittivatko he avoimen opintojen liittyvän omaan ammattialaan vai ei, voitiin huomata, että haasteiden kokemisen suhteen näillä kahdella ryhmällä ei ollut eroa.

Seuraava avovastausten analyysi valottaa tarkemmin, miten opiskelijat sanoittivat opiskelun haasteitaan.

\section{"OTIN LIIAN PALJON OPINTOJA KERRALLA" - HAASTEET OPISKELIJOIDEN KERTOMANA}

Avovastaukset luokiteltiin seuraaviin päluokkiin: työhön liittyvät tekijät, ajankäytön suunnittelemattomuus, opintojen ja odotusten vastaamattomuus, perhesyyt, opiskelutaidot ja itsesäätelykeinot, muihin opintoihin liittyvät tekijät ja opintojen sujuminen ongelmitta.

Työhön liittyvät tekijät ovat suurin yksittäinen syy opintojen vaikeutumiselle tai opintojen keskeyttämiselle. Työhön liittyvät tekijät kertovat samasta eri elämän osa-alueiden yhteensovittamisen ongelmasta kuin kvantitatiivinen aineisto. Lisäksi työpaikalta saadun tuen puute esiintyi selvänä syynä opintojen vaikeutumiselle: "Työpaikan kulttuuri ja ilmapiiri on estänyt opintojen ideaalisen hyödyntämisen työssä ja kollegoiden kesken." Jotkut vastaajat tulkitsivat tuen puutteen merkiksi opintojen vähäisestä arvostamisesta, mikä ei myöskään kannusta opiskelemaan. Työhön liittyviin tekijöihin sisältyi myös ylipäätään työtilan-

Taulukko 2. Opintojen haasteet.

\begin{tabular}{|l|c|}
\hline SUMMAMUUTTUJA JA SIIHEN KUULUVAT VÄITTEET & ka \\
\hline $\begin{array}{l}\text { Elämän eri osa-alueiden yhteensovittamisen haasteet } \\
\text { työn, opintojen ja perheen, ystävien tai harrastusten yhteensovittaminen } \\
\text { palkkatyöhön liittyvästä työmäärästä johtuva ajanpuute } \\
\text { vaikeudet opintojen suunnittelussa lajankäyttöön liittyvät vaikeudet) }\end{array}$ & 3,48 \\
\hline $\begin{array}{l}\text { Itseluottamuksen, motivaation ja opiskelukykyjen haasteet } \\
\text { itseluottamuksen puute, joka liittyy kykyihini suorittaa opintoni loppuun } \\
\text { motivaation puute } \\
\text { tenttiin valmistautumisen vaikeudet } \\
\text { tieteelliseen kirjoittamiseen ja tutkimusmenetelmiin liittyvät vaikeudet } \\
\text { vaikeus ymmärtää opintojen asiasisältöä }\end{array}$ & 1,02 \\
\hline $\begin{array}{l}\text { Vuorovaikutuksen puute } \\
\text { vertaisryhmän vuorovaikutuksen puute } \\
\text { orientoivien opintojen puute } \\
\text { opinto-ohjelmassa vakiintuneiden työ- ja opiskeluryhmien puute }\end{array}$ & 2,11 \\
\hline
\end{tabular}


ne ja haasteet työn ja opiskelun yhteensovittamisessa, mikä heijastui aineistossa omaan jaksamiseen ja elämän osa-alueiden yhteensovittamiseen.

Aineistossa korostui ajankäytön suunnittelemattomuus. Tulokset tukevat tältäkin osin kvantitatiivisia tuloksia. Vastauksissa tuli esille aikapula ja opintojen liiallinen valitseminen, mikä taas johtaa ajankäytön haasteisiin. Todellinen syy voi olla opiskelutaitojen ja -tekniikoiden puuttuminen, mutta tätä ei vastauksista kuitenkaan suoraan voi päätellä. Ajankäytön suunnittelemattomuuteen liittyi myös liiallisten opintojen valitseminen, joita kuvaa hyvin seuraava vastaus: "Keskeytin -- suorittamisen, sillä olin ottanut liian paljon tehtäväksi yhtä aikaa." Tämän kaltaisissa vastauksissa tuli selkeästi esille opiskelijan omien valintojen vaikutus aikapulaan, johon osittain voivat vaikuttaa vaikeudet ajankäytön suunnittelussa ja tietämättömyys opintojen kuormittavuudesta.

Vastauksissa tuli esille opintojen ja odotusten vastaamattomuus. Vastaajat kuvasivat tilanteita, joissa opiskeltava aine ei kiinnostanut tai mielenkiinnon kohde muuttui: "Suorittaessani kyseistä kurssia keksin eri alan, jonka korkeakoulututkintoa halusin hakea opiskelemaan. --." Vastauksissa painottui ennen kaikkea opiskelijan odotusten ja opiskelun todellisuuden välinen ristiriita: "Aloitin kasvatustieteessä, mutta se ei innostanutkaan teorioiden tasolla." Lisäksi jotkut opiskelijat kokivat, etteivät olleet sopeutuneet yliopisto-opintoihin, opetus ei vastannut toiveita tai sen taso oli ollut suorastaan huonoa. Odotuksien vastaamattomuus voi johtua puutteellisesta tiedonsaannista esimerkiksi opinto-oppaissa oppiaineen tai opintojaksojen sisältöjen kuvauksissa.

Perhesyyt aiheuttivat haasteita opinnoissa: sairastumiseen liittyvät vaikeudet, lapsen saanti tai lapsen hoitoon liittyvät syyt ja perheeltä saadun tuen puute. Pääasiassa nämä tulokset ovat linjassa kvantitatiivisten tulosten kanssa. Perheeltä saadun tuen puuttuminen tuo mielenkiintoista lisätietoa aikuisopiskelijan todellisuudesta. Vastauksista tuli esiin joidenkin opiskelijoiden perheiden suhtautuminen yliopistoopiskeluun negatiivisena oman arvon kohottamisena tai ymmärtämättömyytenä. Lisäksi jotkut opiskelijat eivät ole kertoneet opiskelustaan: "En ole kertonut perheelleni, että opiskelen, koska he eivät ehkä pitäisi sitä pe- rusteltuna." Jotkut opiskelijat kokevat ristiriidan perheen odotusten ja oman yliopistollisen opiskelun välillä. Sairastuminen ja vanhemman velvollisuudet näyttäytyivät myös opintoja vaikeuttavina tekijöinä. Sairastumiseen liittyvät vaikeudet liittyivät ennen kaikkea vakaviin sairauksiin ja vanhempien velvollisuudet liittyivät lasten saantiin ja lasten hoitoon. Nämä opiskelua vaikeuttavat tai sen keskeyttämiseen liittyvät syyt ovat ymmärrettäviä sekä henkisen ja fyysisen rasittavuuden että yleisesti elämän osa-alueiden priorisoinnin näkökulmasta. Syynä opintojen vaikeutumiselle tai keskeytymiselle esiintyi myös yleinen elämäntilanne, jota ei kuitenkaan tarkennettu sen enempää: "Elämäntilanne muuttui ja opiskeluun ei yksinkertaisesti tuntunut riittävän aikaa uudessa tilanteessa.".

Vaikka ajankäytön puute ja kiire tuntuivat olevan yleisiä selityksiä opintojen hidastumiselle, oli joissakin vastauksissa käsitelty myös kiireen takana olevia tekijöitä, kuten puutteellisia opiskelutaitoja ja opiskelun itsesäätelykeinoja. Opintojen suunnittelun puutteet ja epäsopiva opiskelutekniikka koettiin opiskelua hidastaviksi tekijöiksi. Opintojen suunnittelun puute ja vaikeudet nähtiin ennen kaikkea yksilön omista kyvyistä johtuviksi. Eräs vastaaja totesikin suoraan: "-- opintosuunnitelmassani ei ollut mitään järkeä -- ." Opiskelutekniikan huonous katsottiin henkilökohtaiseksi syyksi, johon ei ainakaan kyseisissä vastauksissa etsitty syytä tai parannuskeinoa: "Opintotekniikkani oli hukassa ja vähäsen pelästyin asiaa." Vastauksissa esiintyi myös konkreettisesti heikko opintomenestys keskeytymisen tai vaikeutumisen syynä: "Heikko menestys opinnoissa -- en ole oppinut mitään opintojeni aikana."

Vastauksissa tuli esille myös muihin opintoihin liittyvät teemat opintoja vaikeuttavina tai niiden keskeyttämiseen johtavina tekijöinä. Nämä liittyivät valintakokeeseen, tutkinto-opiskelijaksi siirtymiseen, työntekoon tutkinto-opiskelun osana ja opintojen korvaavuuksiin. Perustutkinto-opiskelupaikan saaminen ei luultavasti ole opiskelijalle ongelma vaan tavoite, johon hän on pyrkinyt. Valintakokeeseen ja työntekoon tutkinto-opiskelun osana voidaan ajatella liittyvän ajanpuute tai ajankäytön hallinnan puutteita. Kummassakaan tilanteessa opiskelijan ei voida katsoa keskeyttävän yliopistollisia opintoja, vaan 
suuntaavan voimavaransa yliopistollisten opintojen "eri kohtaan". Esille nousivat myös opintojen korvaavuudet eri yliopistojen tutkintovaatimuksissa. Tällainen tilanne syntyy luultavasti silloin, kun opiskelija suorittaa avoimen yliopiston opintoja korvatakseen myöhempiä perustutkinto-opintoja jossakin toisessa yliopistossa. Kun käy ilmi, että kyseiset opinnot eivät vastaakaan toisiaan, opiskelija keskeyttää avoimen opinnot keskittyäkseen esimerkiksi perustutkintoopiskelijaksi pääsyyn. "Sain tiedon, että ko. yliopiston opinnot eivät suoraan korvaa Helsingin yliopiston kursseja, vaikka samantasoisia --."

Aineistosta löytyi myös vastauksia, joissa opiskelijat kertoivat opintojen sujuneen ongelmitta: "Avoimen yliopiston opinnoista voi selviytyä ilman erikoisempaa tukea, ohjeet ovat selkeät ja verkkosivut informatiiviset." Tällaiset kokemukset ovat luultavasti yleisempiä, mutta eivät luonnollisesti esiinny aineistossa, jossa tutkitaan opiskelun liittyviä haasteita.

\section{POHDINTAA HAASTEISTA}

Työelämän, perhe-elämän ja opiskelun yhteensovittaminen näyttää tämänkin aineiston pohjalta olevan aikuisopiskelijan kestohaaste (vrt. Repo 2010), jonka kanssa taiteilevat kaikki opiskelijat sukupuolesta tai koulutustaustasta riippumatta. Aikapula näyttää helpottavan vasta lähempänä eläkeikää. Lisäksi yllättävät tekijät, kuten sairastuminen perheessä ja työtai elämäntilanteen muutos, saattavat tulla opintojen esteeksi. Nämä ovat tekijöitä, joihin opiskelija ei voi aina itse vaikuttaa. Opintojen esteenä aikapula ja opintojen liian suuri määrä sekä suunnittelun puute ovat jo lähempänä tekijöitä, joihin opiskelija voi itse vaikuttaa. Jotkut opiskelijat tunnistavat, että sopivan määrän valitsemisella, huolellisella aikatauluttamisella ja rytmittämisellä, voi saada tavoittelemansa opinnot suoritettua. Toisaalta osa vastaajista ei tuo esille omien itsesäätelytaitojen merkitystä opintojen etenemiselle (vrt. Haarala-Muhonen, 2011).

Koulutustaustalla oli yhteys opiskelijan itseluottamukseen, motivaatioon ja opiskelutaitoihin, mikä oli oletettavaakin. Mitä paremmalla pohjakoulutuksella avoimeen yliopistoon tulee, sitä paremmat valmiudet on menestyä itsenäisyyttä vaativissa yliopisto-opinnoissa. Sen sijaan mielenkiintoista on, että myös vuorovaikutuksen osalta koulutuksella oli merkitystä. Kun avoimen yliopiston opiskelijoita kannustetaan hakemaan tukea vertaisiltaan, on hyvä olla tietoinen siitä, että eritaustaisilla opiskelijoilla voi olla erilaiset samaistumiskohteet. Revon (2010) mukaan avoimen yliopiston opiskelija ei välttämättä samaistu toisiin opiskelijoihin vaan hakee vertaistuen esimerkiksi työpaikaltaan tai perheestään. Toisaalta aineistossa näkyi myös se, että perhe ei välttämättä tue avoimen yliopiston opiskelijaa ja heidän täytyy suorastaan opiskella salaa perheeltään.

Avoimen yliopiston opiskelijat ovat yleensä motivoituneita opiskelemaan (vrt. Repo, 2010). Aineistossa nousee kuitenkin esiin, että opinnot eivät ole vastanneet odotuksia tai että motivaatio muuttuu opintojen kuluessa. Motivaation muutosta opintojen edetessä avoimessa yliopistossa kuvataan myös Sirkkasen (2009) tutkimuksessa. Voidaan ajatella, että aineistomme antaa tukea Uusitalon (2012) tuloksille opiskelusta elämänrakenteen osana. Opiskelumotivaatio ja tavoitteiden saavuttaminen liittyvät siihen, minkä osan elämänrakenteessa opiskelu saa. Avoin yliopisto tarjoaa opiskelijalle mahdollisuuden tutustua eri oppiaineisiin ja etsiä omaa kiinnostuksen kohdetta. Helsingin yliopiston sisäisessä selvityksessä vuonna 2007 todettiin, että Avoimessa yliopistossa opiskelleet opiskelijat vaihtoivat pääainetta selvästi harvemmin kuin opiskelijat, jotka eivät olleet opiskelleet Avoimessa yliopistossa (Hirvonen 2007). Oman motivaation ylläpitäminen aktiivisesti on myös osa itsesäätelytaitoja ja sitä voi oppia (Heikkilä \& Lonka 2006). Vaikka tutkimuksessamme etsimme syitä, jotka ovat vaikeuttaneet opiskeluja tai aiheuttaneet niiden keskeytymisen, on muistettava, että opintojen keskeyttämistä ei pidä nähdä vain negatiivisena asiana. Opiskelijan kannalta keskeyttäminen voi olla myös mielekäs ja tarpeellinen ratkaisu omassa elämäntilanteessa.

Tutkimusaineisto koostui kahdesta eri kyselystä. Vastaajien määrä oli melko suuri, yhteensä 680, mutta vastausprosentit jäivät alhaisiksi (17\% ja $21 \%$ ). Opiskelijoista valtaosa ei siis vastannut kyselyyn. Näin jotkin opiskelun haasteet, jotka ovat opiskelijoille merkityksellisiä, eivät ehkä tule esiin tässä aineistossa. Tulosten tulkinnassa on lisäksi huomi- 
oitava, että vastaajissa oli enemmän naisia, he olivat keskimäärin hieman vanhempia ja koulutetumpia kuin Helsingin yliopiston Avoimen yliopiston opiskelijat olivat vuoden 2011 tilaston mukaan. Toisaalta sukupuolien välillä ei ollut eroa ainakaan siinä, miten paljon erilaisia opiskelun haasteita miehet ja naiset olivat kokeneet.

Tutkimuksen luotettavuutta lisää, että tutkimuskysymyksiin on haettu vastauksia sekä kvantitatiivisesti että kvalitatiivisesti. Kvantitatiivisista tuloksista ja sisällönanalyysillä tehdyistä luokitteluista saatiin vastauksia opiskelun haasteisiin. Näin on saatu monipuolinen näkemys opiskelua edistävistä ja hidastavista tekijöistä. Toisaalta opiskelijoiden antamat selitykset voivat olla sosiaalisesti hyväksyttyjä, yksinkertaisia "pintaselityksiä", eikä tällaisilla tutkimusmenetelmillä päästä käsiksi monimutkaisempiin syihin.

Lisäksi on muistettava, että opiskelun haasteita mittaava mittari ei perustunut yhteen teoriaan vaan oli syntynyt kansainvälisen tutkimusryhmän yhteistyön tuloksena neljän eri maan opiskelukontekstiin soveltuvaksi. Konfrimatorisen faktorianalyysin pohjalta saatiin faktorit, joiden pohjalta muodostettujen summamuuttujien reliabiliteetit olivat hyvät. Faktorit olivat siinä kontekstissa ja suhteessa toisiinsa mielekkäästi tulkittavissa jokainen omaksi näkökulmakseen avoimen opiskelijan opiskeluhaasteisiin. Kuitenkin erityisesti faktori, johon latautuivat motivaatioon, itsetuntoon ja opiskelutaitoihin liittyvät väittämät, on melko yleistävä ja niputtaa yhteen laajoja opiskeluun liittyviä osa-alueita, joista on jo paljon tutkimustietoa. Opiskelumotivaatioon, itsetuntoon, joka tulee lähelle minäpystyvyysuskomuksia ja opiskelutaitoihin on jokaiseen hienosyisempiä teorioita ja näihin pohjautuvia, testattuja mittareita, joiden avulla kysymyksiin päästäisiin huolellisemmin kiinni. Tällaisia ovat esimerkiksi ILS, Inventory of Learning Styles (Vermunt 1998) ja MSLQ, Motivated Strategies for Learning Questionnaire (Pintrich 2000, 2003b).

Vastaajista kaikki olivat avoimen yliopiston opiskelijoita. Virallisen tilaston mukaan vuonna 2011 vähän alle kolmasosa Helsingin yliopiston Avoimen yliopiston opiskelijoista oli myös perustutkinto-opiskelijoita. Näin oli myös OPULL-aineistossa, jossa 31 prosenttia vastaajista ilmoitti olevansa samaan aikaan
JOTKUT OPISKELIJAT

KOKEVAT RISTIRIIDAN

PERHEEN ODOTUSTEN JA

OMAN YLIOPISTOLLISEN

OPISKELUN V ̈̈LILL ̈̈.

myös tutkinto-opiskelijana jossain oppilaitoksessa. Tuloksia voidaan siis jossain määrin yleistää yliopisto-opiskelijoihin laajemminkin.

\section{MISTÄ TUKEA AVOIMEN YLIOPISTON OPISKELIJALLE?}

Helsingin yliopiston Avoimessa yliopistossa opintojen ohjaus on rakennettu osaksi oppimisympäristöjä: opintokokonaisuudet alkavat orientaatiotilaisuudella, jossa voi tavata opettajan, suunnittelijan, sihteerin, tuutorin ja joskus "vanhemman" opiskelijan. Orientaatiotilaisuuksissa autetaan opiskelijoita luomaan kontakteja tuleviin opiskelutovereihin. Tarjolla on myös henkilökohtaista ohjausta opintojen suunnitteluun puhelimitse, sähköpostitse, verkkokokousympäristössä tai henkilökohtaisella vastaanottokäynnillä. Avoimessa yliopistossa opiskelijoille on myös tarjolla erilaisia opiskelutaidollisia kursseja ja teemailtoja opintojen eri vaiheissa. Oppimisen ja opiskelun ohjaus eivät avoimessa yliopistossa ole erillisiä vaan limittyvät esimerkiksi niin, että verkko-opintojaksolle laaditaan opiskelua ohjaavia elementtejä (Herno \& Laitinen 2007, 203-207). Avoimen yliopiston verkkosivuilla on myös laaja osio opiskelun taidoista sekä tallenteita opiskelutaitoilloista ja oppimisvaikeuksista. Vuonna 2013 tehdyillä verkkosivuilla opiskelijoita kannustettiin hyödyntämään vertaistukea opinnoissaan (Repo \& Tommila 2014). Myös opettajille on omat sivunsa ja heitä on koulutettu vertaistuen käynnistämiseen kursseilla. Verkkosivujen kehittämisen haasteena on kuitenkin se, miten opiskelijat löytävät tarvitsemansa tiedon laajasta tietomäärästä. Aikuisopiskelijoiden ohjausta ja tukea tulisi kehittää entistä enemmän opiskelijalähtöisesti ja etenkin aikuisopiskelijoiden elämäntilannelähtöisesti.

Usealla aikuisopiskelijalla on avoimen yliopiston 
opinnoissa ammatillisia tavoitteita (Haltia 2012). Työelämän muuttumisen ja ammatillisten tavoitteiden myötä uravalinnan ohjaus tulee olemaan jatkossa avoimessa yliopistossa yhä tärkeämpää, joten sitä pitäisi kehittää. Osa aikuisopiskelijoista harkitsee tai tavoittelee uran vaihtamista. Yliopisto-opinnoissa oman uraidean ja erityisyyden löytäminen on tärkeää (Lairio \& Penttinen, 2005, 32). Avoimessa yliopistossa voitaisiin kehittää yhteistyötä työnantajien kanssa. Iso-Britannian avoimessa yliopistossa (Open University) on kokeiltu ns. kolmikantaneuvotteluja, joissa osapuolina ovat opiskelija, hänen työnantajansa ja avoin yliopisto (suullinen tieto Open University'n yhteiskuntavastaava Dominic Newbouldilta keväällä 2011). Tällaiset työtavat voisivat sitouttaa sekä opiskelijaa että työnantajaa opintoihin, ja opiskelijalle ja työnantajalle tulisi entistä selvemmäksi opiskelun tavoitteet. Opiskelija saisi oikeutettua opiskelunsa myös työnantajan näkökulmasta ja samalla tarvitsemaansa tukea tavoitteen saavuttamiseen.

Aikuisopiskelijan perhe ei aina suinkaan suhtaudu kannustavasti aikuisopiskeluun. Opiskeluun käytetty aika on poissa perheen yhteisestä ajasta. Perheenjäsenen yliopistolliset opinnot ja niihin liittyvä mahdollinen identiteetin muutos tai koettu sosiaalinen arvonnousu voivat tuntua ei-opiskelevista perheenjäsenistä uhkaavilta. Avoimen yliopiston opintojen ohjauksessa puhutaan ehkä liiankin vähän siitä, mikä merkitys ympäristön tuella on opinnoissa. Jos esimerkiksi perheeltä ei saa riittävää tukea, opiskelijoiden muodostama vertaisryhmä voisi toimia tukena. Avoin yliopisto voisi tukea ja mahdollistaa tällaista toimintaa.

Tutkimusaineistossa tuli esille ajankäyttöön liittyvät opiskeluhaasteet. Omien opiskelutavoitteiden kirkastaminen osana muuta elämää voisi johtaa aikaisempaa realistisempiin suunnitelmiin ja sitä kautta tyytyväisyyteen, kun opiskelija saavuttaa asetta- mansa tavoitteet omassa tavoiteajassaan. Tämä tarkoittaa vastuun ottamista omista opinnoista, jolloin opintojen hidastumisen selittäminen kiireellä ei enää olisikaan riittävä syy. Ajankäyttöön liittyy myös opintojen mitoitus sekä tieto eri opintojen ja suoritustapojen kuormittavuudesta. Opiskelijoille voidaan myös tarjota valmiita esimerkkejä eri suoritustapojen kuormittavuudesta, kalenteripohjia, kalenteriesimerkkejä ja välineitä oman ajankäytön arvioimiseen. Ajankäyttöön liittyvän tietoisuuden lisäämistä voitaisiin edistää neuvonnan ja ohjauksen keinoin. Opiskelijat voisivat saada ohjausta opiskelun liittämisestä ja mitoittamisesta osaksi elämänsä kokonaisuutta. Tällainen ohjaus voisi auttaa opiskelijaa tekemään aikaisempaa realistisempia suunnitelmia, jolloin asetettujen tavoitteiden saavuttaminen lisäisi opiskelijan tyytyväisyyttä ja minäpystyvyysuskomuksia. Opiskelijoiden minäpystyvyysuskomuksiin tulisikin kiinnittää entistä enemmän huomiota myös ohjauksellisin keinoin. Avoimen yliopiston työntekijät voisivatkin panostaa myös opiskelijoiden kannustamiseen. Kannustamisella voidaan auttaa opiskelijaa huomaamaan omia vahvuuksiaan ja luottamaan omiin kykyihinsä (Onnismaa, 2007, 31).

Aikuisopiskelijoiden elämään liittyy myös opiskelunhaasteita, jotka ovat avoimen yliopiston vaikutuspiirin ulkopuolella. Kuitenkin henkilökohtaisella ohjauksella, joustavilla opiskeluratkaisuilla, erilaisilla opintopoluilla ja opinto-oikeusajoilla opintojen etenemistä voidaan helpottaa erilaisissa elämäntilanteissa. Jatkossa tulisi tutkia opiskelun ohjausta enemmän erilaisessa elämäntilanteessa olevien aikuisopiskelijoiden näkökulmasta. Myös perheen tuesta aikuisopiskelussa tarvittaisiin lisää tietoa. Luultavasti toisille opiskelijoille riittää kirjallinen tieto, mutta toiset hyötyisivät holistisemmasta ohjauksesta, jossa otettaisiin huomioon opiskelijan koko elämäntilanne ja se, minkälaista tukea he voivat saada ympäristöstään. Tästäkin aiheesta lisätutkimus olisi paikallaan. 


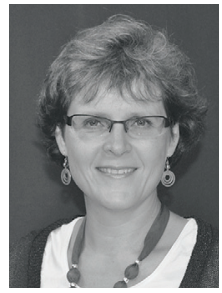

Saara Repo

FT, pedagoginen yliopistonlehtori Helsingin yliopiston Avoin yliopisto Kuva: Ulla Jokila

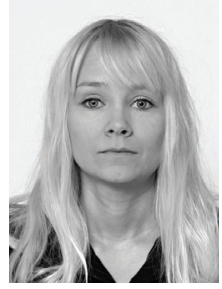

Satu-Tuulia Vuoksenranta

KM, koulutussuunnittelija

Maanpuolustuskorkeakoulu

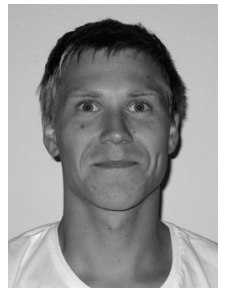

Otto Ruokolainen

VTM, tutkija

Terveyden ja hyvinvoinnin laitos

\author{
Kiitämme käsikirjoituksemme \\ kommentoinnista Pirkko Raudaskoskea, \\ Tiina Renkoa ja Sanna Vehviläistä.
}

\section{LÄHTEET}

Bandura, A. (1977). Self-efficacy: Toward a Unifying Theory of Behavioral Change. Psychological Review 84 (2), 191-215.

Guri-Rosenblit, S. (1999). Distance and Campus Universities: Tensions and Interactions. A Comparative Study of Five Countries. Pergamon.

Haarala-Muhonen, A. (2011). Oikeustieteen ensimmäisen vuoden opiskelijoiden haasteet opiskelussa. Helsingin yliopisto. Käyttäytymistieteiden laitos. Kasvatustieteellisiä tutkimuksia 237.

Hailikari, T. \& Sjöblom, A. (2012). Opintojen etenemiseen vaikuttavat syyt. Projektin loppuraportti. Helsingin yliopisto, Humanistinen tiedekunta. http://www. helsinki.fi/hum/hallinto/opintojen-etenemisen-syyt. pdf. Luettu 26.4.2013.

Haltia N. (2012). Yliopiston reunalla - Tutkimus suomalaisen avoimen yliopiston muotoutumisesta. Turku: Turun yliopisto.

Heikkilä A. \& Lonka K. (2006) Studying in higher education: students' approaches to learning, self-regulation, and cognitive strategies. Studies in Higher Education 31(1).

Herno M. \& Laitinen M. (2007). Aikuisopiskelijan tuki ja ohjaus. Teoksessa Kosunen T., Jouttimäki S., Nisula E.-L. \& Nurminen E. Avoin yliopisto. Sivistystä, osaamista ja tasa-arvoa. Helsinki: Gaudeamus.

Korhonen, V. (2012) Towards inclusive higher education? Outlining a student-centered counseling framework for strengthening student engagement. Teoksessa
Stolz S. \& Gonon P. (toim.) Challenges and Reforms in Vocational Education - Aspects of Inclusion and Exclusion. Bern: Peter Lang, 297-320.

Lairio M. \& Penttinen L. (2005). Kohti uutta ohjauskulttuuria. Teoksessa Nummenmaa A.R., Lairio M., Korhonen V. \& Erola S. (toim.). Ohjaus yliopiston oppimisympäristössä. Tampere: Tampere University Press.

Lähteenoja, S. (2010). Uusien opiskelijoiden integroituminen yliopistoon: sosiaalipsykologinen näkökulma. Helsingin yliopisto. Sosiaalipsykologisia tutkimuksia 23.

Müller, R. \& Repo, S. (2013). Careerists or Educational Aspirants? - (Re-)entry of European Lifelong Learners into Higher Education. Lifelong Learning in Europe. 2013, 2.

Mäkinen M. \& Annala J. (2011). Opintoihin kiinnittyminen yliopistossa. Teoksessa Mäkinen M., Korhonen V., Annala J., Kalli P., Svärd P. \& Värri V.-M. (toim.). Korkeajännityksiä. Kohti osallisuutta luovaa korkeakoulutusta. Tampere: Tampereen yliopisto.

Onnismaa J. (2007). Ohjaus- ja neuvontatyö. Aikaa, huomiota ja kunnioitusta. Helsinki: Gaudeamus kirja.

Partanen A. (2011). "Kyllä minä tästä selviän": aikuisopiskelijat koulutustarinansa kertojina ja koulutuksellisen minäpystyvyytensä rakentajina. Kokkola: Chydenius-instituutti.

Pasanen H. (2001). Itseohjautuvuus aikuiskoulutuksessa. Aikuiskasvatus 30(1). 
Pintrich P.R. (2003a). A Conceptual Framework for Assessing Motivation and Self-Regulated Learning in College Students. Educational Psychology Review, 16(4), 385-405.

Pintrich, P.R. (2000). Multiple goals, multiple pathways: The role of goal orientation in learning and achievement. Journal of Educational Psychology, 92(3), 544-555.

Pintrich, P. R. (2003b) A Motivational Science Perspective on the Role of Student Motivation in Learning and Teaching Contexts. Journal of Educational Psychology, 95(4), 667-686.

Purtilo-Nieminen, S. \& Määttä, K. (2011). Admission to university: Narratives of Finnish open university students. International Journal of Continuing Education and Lifelong Learning, 3(2), 43-55.

Repo, S. (2010). Yhteisöllisyys voimavarana yliopistoopetuksen ja -opiskelun kehittämisessä. Helsingin yliopisto. Käyttäytymistieteiden laitos. Kasvatustieteellisiä tutkimuksia 228.

Repo, S. \& Tommila, O. (2014) Opitaan yhdessä projekti Avoimessa yliopistossa. Esitys Helsingin yliopiston Oppimisseikkailussa 4.3.2014.

Rinne, R., Jauhiainen, A., Tuomisto, H., Alho-Malmelin, M., Halttunen, N. \& Lehtonen, K. (2003). Avoimen yliopiston opiskelija - kokovartalokuvasta eriytyneisiin muotokuviin. Turun yliopiston kasvatustieteiden tiedekunnan julkaisuja. Turku: Turun yliopisto.

Sirkkanen H. (2008). Opiskelun moninaisia merkityksiä Avoimessa yliopistossa. Diskurssianalyysiä ammatillisen osaamisen kehittämisen motiivista opiskelevien haastattelupuheesta. Pro gradu -työ. Helsingin yliopisto.

Tuomi J. \& Sarajärvi A. (2003). Laadullinen tutkimus ja sisällönanalyysi 1. 2. painos. Helsinki: Tammi.

Törmä S \& Mäkinen S. (2012). Avoimen yliopiston opiskelijat opintojen merkityksiä rakentamassa ja opiskelutaitoja kehittämässä. Teoksessa Mäkinen Marita et al. (toim.) Osallistava korkeakoulutus. Tampere: Tampere University Press, 75-99.
Uusitalo A. (2012). Aikuisena yliopistossa elämänrakenteiden vaikutus yliopisto-opintojen sujuvuuteen. Pro gradu -työ. Tampereen yliopisto.

Vermunt, J. (1998) The Regulation of Constructive Learning Processes. British Journal of Educational Psychology (1998), 68, 149-171.

Vermunt, J. D. \& Vermetten, Y. J. (2004). Patterns in student learning: Relationships between learning strategies, conceptions of learning, and learning orientations. Educational Psychology Review, 16(4), 359-384.

Wenger E. (1998). Communities of practice. Learning, meaning and identity. United Kingdom: Cambridge University Press.

Zimmerman, B. J. (2000). Attaining self-regulation: a social cognitive perspective, in: Boekaerts, $M$. Pintrich P. \& Zeitner M. (Eds). Handbook of selfregulation. San Diego, CA, Academic Press.

\section{JULKAISEMATTOMAT LÄHTEET}

Helsingin yliopiston Avoimen yliopiston sisäinen tilasto 2012.

Hirvonen, J. (2007). Helsingin yliopiston Avoimessa yliopistossa opiskelun ja valmistumisajan sekä pääaineenvaihtoherkkyyden väliset suhteet tiedekunnittain. (ei julkaistu)

\section{VERKKOLÄHTEET}

Helsingin yliopiston LEARN-palautejärjestelmä. http://www.helsinki.fi/yty/oppi/laatutyovalineena. htm. Luettu 26.2.2014.

http://www.avoin.helsinki.fi/opiskeluntaito/opitaan_ yhdessa.htm. Luettu 24.6.2014.

http://www.avoin.helsinki.fi/opettajille/opiskelijoiden_ vertaistuki.htm. Luettu 24.6.2014. 